\begin{tabular}{|c|c|c|}
\hline & Int.J.Curr.Microbiol.App.Sci (2021) 10(12): 28-35 & \\
\hline EXCELLENT & $\begin{array}{l}\text { International Journal of Current Microbiology and Applied Sciences } \\
\text { ISSN: 2319-7706 Volume } 10 \text { Number } \mathbf{1 2}(\mathbf{2 0 2 1 )} \\
\text { Journal homepage: http://www.ijcmas.com }\end{array}$ & 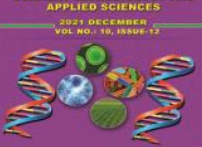 \\
\hline $\begin{array}{l}\text { EXCELLENT } \\
\text { PUBLISHERS }\end{array}$ & & \\
\hline
\end{tabular}

Original Research Article

https://doi.org/10.20546/ijcmas.2021.1012.005

\title{
Disposable Pattern of Black Gram in Jhansi District of Uttar Pradesh, India
}

\author{
Ameesh John Stephen*, Rakesh Kumar Mishra and Setu Ratnam \\ Department of Agriculture Economics, SHUATS, India \\ *Corresponding author
}

\begin{abstract}
A B S T R A C T
Keywords

Black gram respondents, Peak period, Supply chain, Marketing cost, Price Spread, Marketing margin

Article Info

Received: 05 November 2021 Accepted:

30 November 2021 Available Online: 10 December 2021 markets.

\section{Introduction}

India is world's largest producer of pulses with its total pulse production contributing a quarter of world's total production. While one-third of world's total acreage under pulses is in India, Indian population consumes $30 \%$ of world's total pulses. However, domestic production of pulses has not kept pace with population growth. Total pulses production of 17.33 million tons during 2015-16 is marginally higher than the previous year's production of 17.15 million tons. Black gram (urad), mostly produced in Asian countries as
\end{abstract}

India total pulse production contributing a quarter of world's total production which make them world's largest producer of pulses. While one-third of world's total acreage under pulses is in India, Indian population consumes $30 \%$ of world's total pulses in global production. Chickpea, pigeonpea, mungbean, uradbean, lentil are important pulses crop contributing 39 per cent, 21 per cent, 11 per cent, 10 per cent, and 7 per cent to the total production of pulses in the country. The study suggested that modern market infrastructure may be built up with the public-private partnership to bring efficiency in the marketing of Black gram as well as other pulses. The study suggested that Black gram respondents may prefer cooperative/group marketing for sale of their produce in the distant their climate and soil type suits its cultivation. India is largest producer of this pulse followed by Myanmar and Thailand. India produces $70 \%$ of worlds' black gram production and Black gram accounts for $10 \%$ of total pulse production in India. In absolute terms, 1.5 million tons of Black Gram is produced from 2.5 million hectare area with an average productivity of about $600 \mathrm{~kg}$ per hectare.

Despite being largest producer of black gram, India is not in a comfortable situation as it is also the largest consumer of black gram. India is also the largest importer of pulse in spite of 
one of largest producer. Andhra Pradesh, Madhya Pradesh, Maharashtra, Uttar Pradesh, Punjab, West Bengal, Orissa, Tamil Nadu, and Karnataka are the major states producing black gram in India (Acharya, 2012). While Andhra Pradesh contributes 24\% of total production, Maharashtra and Madhya Pradesh contributes $20 \%$ and $13 \%$ respectively (Gupta S. K, 2001). In this context, the proposed study understands post-harvest issues related to black gram leading to crop losses.

Black gram, also known as Urdbean, mash, black maple etc. an important short-duration pulse crop grown in many parts of India. This crop is grown in cropping systems as a mixed crop, catch crop, sequential crop besides growing as sole crop under residual moisture conditions after the harvest of rice and also before and after the harvest of other summer crops under semi-irrigated and dry land conditions (Shamim, 2005).

Its seeds are highly nutritious with protein (25-26\%), carbohydrates (60\%), fat (1.5\%), minerals, amino acids and vitamins. Seeds are used in the preparation of many popular dishes, e.g. dosa, idli, vada etc. Black gram has been distributed mainly in tropical to subtropical countries where it is grown mainly in summer season. It is grown in India, Pakistan, Sri-Lanka, Burma, and some countries of South East Asia. In India black gram is very popularly grown in Andhra Pradesh, Bihar Madhya Pradesh, Maharashtra, Uttar Pradesh, West Bengal, Punjab, Haryana, Tamil Nadu and Karnataka with an area of about 3.29 million ha with a total production of 1.60 million tones with an average productivity of $485 \mathrm{~kg} / \mathrm{ha}$. Andhra Pradesh leads with the highest productivity followed by Orissa. 'Kalodal' or 'Panhelo dal' as it is known in Sikkim, is extensively cultivated in all the dry belts of South and West districts of Sikkim (Deoghare B 1992). In Sikkim total area under Urd cultivation is 3.55 thousand hectare production is 2.78 thousand Tonnes and productivity is $783.10 \mathrm{~kg} / \mathrm{ha}$.

\section{Uttar Pradesh Market}

Uttar Pradesh was among largest economy in India after Maharashtra and Tamil Nadu. Between 2004 and 2015, the economy grew only $4.4 \%$ per year, one of the lowest rates in India. But between 2007 and 2011 under the Mayawati govt., the economy grew at over $7 \%$ GDP growth rate in the time when Indian economy faced the melt down due to global recession. Furthermore, UP has been one of the five state including Bihar, Chhattisgarh, Punjab, Maharashtra, have registered growth rates higher than their respective targets set for the 12th Plan period (2012-17) so far.

\section{Materials and Methods}

There are 7 community development blocks in Jhansi district, where all are involved in black gram production. Moth block was purposively selected on the basis of highest area (1008 hectares) under the black gram cultivation among all blocks of the Jhansi district. It is a town and a nagar panchayat in jhansi district in the Indian state of Uttar Pradesh. Moth has a population of 17175 . Males constitute $54 \%$ of the population and females $46 \%$. Moth has an average literacy rate of $53 \%$, lower than the national average of 59.5\%: male literacy is $64 \%$, and female literacy is $40 \%$. In Moth, $16 \%$ of the population is under 6 years of age.

The information regarding present Black gram grower were collected through personal interviews with the help of structured schedule in the light of objectives of the study. Most of the interview held during free time of the respondents at their homes are farms in randomly selected villages the all black gram grower were categorized and classification in to three size groups on the basis of size of holdings. Then, 10\% sample respondents/ 
growers were selected by random sampling technique from each randomly selected villages in all three different size of farms group. Altogether, 70 respondents were selected randomly in all the three categories viz; 35 small size, 21 medium size and 14 large size respondents respectively.

Table. 1 shows the distribution of total number of farmers of different size groups and selected black gram grower (farmers) from each village:

\section{Selection of market}

Primary market: Moth Mandi

Secondary market: Jhansi Mandi (near bus stand)

Moth Mandi was selected on the basis of highest arrival of Black gram in the market for studying the marketing cost, margin and price spread in different channels involved in marketing of Black gram.

\section{Selection of intermediaries}

Investigation regarding different marketing channels involved in black gram marketing was done by selecting a random sample of such intermediaries as commission agents, wholesalers, dal millers and retailers. Ten commission agents, ten wholesalers, ten retailers and two millers were selected randomly to study marketing cost, price spread in different marketing channels.

\section{Results and Discussion}

\section{Marketing channels of black gram}

The channels of marketing of agricultural produce from producer to consumer vary from commodity to commodity and area to area. The chain of intermediaries through which product moves from producer to consumer constitute their marketing channels. There were two common marketing channels identified in marketing of black gram in the study area.

These were:-

\section{Channel-I}

Producer $\rightarrow$ Commission agent $\rightarrow$ Wholesaler $\rightarrow$ Dal miller $\rightarrow$ Retailer $\rightarrow$ Consumer

\section{Channel-II}

Producer $\rightarrow$ Commission agent $\rightarrow$ Dal miller $\rightarrow$ Retailer $\rightarrow$ Consumer

Cost and margin in black gram in different channels

The magnitude of cost incurred and margin earned in marketing of a commodity is an indicator of the marketing efficiency. Generally, the higher magnitude of costs and margin, the lower the efficiency of marketing system. Thus knowledge of marketing costs and margin is necessary for bringing improvement in the efficiency of marketing system. Therefore, an attempt has been made to analyze the cost incurred; margins earned and relative share of intermediaries in consumer rupee and the result are presented in Table. 2 and Table. 3.

\section{Marketing cost of black gram in Different Marketing Channels}

Marketing cost of black gram in Channel I (Producer $\rightarrow$ Commission agent $\rightarrow$ Wholesaler $\rightarrow$ Dal miller $\rightarrow$ Retailer $\rightarrow$ Consumer)

The marketing costs in channel-I (Table.2) indicates that the cost incurred by producer was Rs. 90 per quintal of black gram which 
was 1.04 per cent of consumer rupee. Cost incurred by commission agent was Rs. 92.32 per quintal of black gram which was 1.17 per cent of consumer rupee. Cost incurred by wholesaler was Rs. 303.30 per quintal of black gram which was 3.62 per cent of consumer rupee. Cost incurred by dal miller was Rs. 620 per quintal of black gram which was 3.76 per cent of consumer rupee. Cost incurred by retailer was Rs. 130 per quintal of black gram which was 0.97 per cent of consumer rupee. The farmer share in the consumer rupee was 69.48 per cent in channel-I.

\section{Marketing cost of black gram in Channel II} (Producer $\rightarrow$ Commission agent $\rightarrow$ Dal miller $\rightarrow$ Retailer $\rightarrow$ Consumer)

The marketing cost in channel-II (Table.3) indicates that the total cost incurred by producer was Rs. 90 per quintal of black gram which was 1.07 per cent of consumer rupee.
Cost incurred by commission agent was Rs. 94.6 per quintal of black gram which was 1.06 per cent of consumer rupee. Cost incurred by miller was Rs. 865.38 per quintal of black gram which was 4.74 per cent of consumer rupee. Cost incurred by retailer was Rs. 130 per quintal of black gram which was 1.54 per cent of consumer rupee. The farmer share in consumer rupee was 65.84 per cent. These tables indicate that channel II was the best as it ensured higher share in consumer rupee for the farmer.

\section{Price spread of black gram in channel I}

The perusal of Table. 4 reveals that producer share in consumer rupee was 65.17 per cent and price spread was as high as 27.58 per cent, out of which, 10.57 per cent was accounted for by marketing cost and 16.99 per cent was accounted for by margin.

Table.1 Classification of black gram grower (farmers) in different size holdings

\begin{tabular}{|c|c|c|}
\hline S.No. & Category of farmers & Size of land holding (Ha.) \\
\hline $\mathbf{1 .}$ & Small & Below 1 hectare \\
\hline $\mathbf{2}$. & Medium & 1 hectare -2 hectares \\
\hline $\mathbf{3}$. & Large & Above 2 hectares \\
\hline
\end{tabular}

Table.2 Number of selected farmers from each village

\begin{tabular}{|l|c|c|c|c|c|}
\hline \multirow{2}{*}{ S.No. } & Name of villages & \multicolumn{3}{|c|}{ Size groups } & \multirow{2}{*}{ Grand Total } \\
\cline { 3 - 5 } & & Small & Medium & Large & \\
\hline 1. & Chalera & 04 & 03 & 01 & 08 \\
\hline 2. & Semri & 06 & 02 & 02 & 10 \\
\hline $\mathbf{3 .}$ & Dineri & 05 & 03 & 02 & 10 \\
\hline $\mathbf{4 .}$ & Tehorka & 08 & 04 & 01 & 13 \\
\hline $\mathbf{5 .}$ & Labhera & 07 & 02 & 02 & 11 \\
\hline $\mathbf{6 .}$ & Erach & 06 & 02 & 02 & 10 \\
\hline $\mathbf{7 .}$ & Khilla & 03 & 04 & 01 & 08 \\
\hline & Total & 39 & 23 & 11 & 70 \\
\hline
\end{tabular}


Table.3 Marketing cost of black gram I (P-CA-WS-R-C)

\begin{tabular}{|c|c|c|}
\hline Particulars & Rs./qt. & $\begin{array}{l}\text { \% share in consumer } \\
\text { rupee }\end{array}$ \\
\hline Net price received by producer & 5400.00 & 64.17 \\
\hline \multicolumn{3}{|c|}{ Cost incurred by producer } \\
\hline Loading charges & 10.00 & 0.06 \\
\hline Unloading charges & 10.00 & 0.06 \\
\hline Transportation & 30.00 & 0.41 \\
\hline Cost of gunny bags & 30.00 & 0.41 \\
\hline Charges of grading & 10.00 & 0.06 \\
\hline Total cost & 90.00 & 1.04 \\
\hline Producer sale price/CA purchase price & 5490.00 & 65.47 \\
\hline \multicolumn{3}{|c|}{ Cost incurred by CA } \\
\hline Mandi tax@1.5\% & 82.32 & 1.10 \\
\hline Weighing & 10.00 & 0.06 \\
\hline Total cost & 92.32 & 1.11 \\
\hline Net margin of CA & 250.00 & 3.02 \\
\hline $\begin{array}{l}\text { Sale price of CA / } \\
\text { purchase price of Wholesaler }\end{array}$ & 5832.32 & 70.73 \\
\hline \multicolumn{3}{|l|}{ Cost incurred by Wholesaler } \\
\hline Sale tax @ 4\% & 233.30 & 3.06 \\
\hline Loading charges & 10.00 & 0.06 \\
\hline Unloading charges & 10.00 & 0.06 \\
\hline Transportation & 50.00 & 0.41 \\
\hline Total cost & 303.30 & 3.63 \\
\hline Net margin of wholesaler & 350.00 & 4.22 \\
\hline Sale price of wholesaler/purchase price of Dal miller & 6485.62 & 78.84 \\
\hline \multicolumn{3}{|l|}{ Cost incurred by Dal miller } \\
\hline Transportation charges from mandi to shop & 50.00 & 0.41 \\
\hline Labour charges for loading and unloading & 20.00 & 0.13 \\
\hline Storage facilities & 50.00 & 0.41 \\
\hline Processing & 500.00 & 2.78 \\
\hline Total cost & 620.00 & 3.76 \\
\hline Net margin of miller & 500.00 & 4.17 \\
\hline $\begin{array}{c}\text { Value of husk@ Rs.5 /kg assuming grain, husk ratio } \\
\text { of 90:10 per qtls. }\end{array}$ & 50.00 & 0.27 \\
\hline Total net margin of miller & 550.00 & 4.44 \\
\hline Sale price of Dal miller/Purchase price of retailer & 7655.62 & 92.06 \\
\hline \multicolumn{3}{|c|}{ Cost incurred by retailer } \\
\hline Transportation charges from mandi to shop & 50.00 & 0.41 \\
\hline Labour charges for loading and unloading & 30.00 & 0.13 \\
\hline Storage facilities & 50.00 & 0.41 \\
\hline Total cost & 130.00 & 1.57 \\
\hline Net margin of retailer & 550.00 & 6.94 \\
\hline Sale price of retailer /Purchase price of consumer & 8335.62 & $100 \%$ \\
\hline
\end{tabular}


Table.4 Marketing cost of black gram II (P-CA-M-R-C)

\begin{tabular}{|c|c|c|}
\hline Particulars & Rs./qt. & $\begin{array}{l}\text { \% share in consumer } \\
\text { rupee }\end{array}$ \\
\hline Net price received by producer & 5550.00 & 66.48 \\
\hline \multicolumn{3}{|c|}{ Cost incurred by producer } \\
\hline Loading charges & 10.00 & 0.20 \\
\hline Unloading charges & 10.00 & 0.20 \\
\hline Transportation & 30.00 & 0.60 \\
\hline Cost of gunny bags & 30.00 & 0.06 \\
\hline Charges of grading & 10.00 & 0.01 \\
\hline Total cost & 90.00 & 1.07 \\
\hline Producer sale price/CA purchase price & 5640.00 & 66.91 \\
\hline \multicolumn{3}{|c|}{ Cost incurred by CA } \\
\hline Mandi tax@1.5\% & 84.6 & 1.05 \\
\hline Weighing & 10.00 & 0.02 \\
\hline Total cost & 94.6 & 1.06 \\
\hline Net margin of $\mathrm{CA}$ & 400.00 & 4.74 \\
\hline $\begin{array}{c}\text { Sale price of CA/Purchase price of Dal } \\
\text { miller }\end{array}$ & 6134.6 & 72.77 \\
\hline \multicolumn{3}{|c|}{ Cost incurred by miller } \\
\hline Sale tax@4\% & 245.38 & 2.9 \\
\hline $\begin{array}{l}\text { Transportation charges from mandi to } \\
\text { shop }\end{array}$ & 50.00 & 0.59 \\
\hline Labour charges for loading and unloading & 20.00 & 0.23 \\
\hline Storage facilities & 50.00 & 0.59 \\
\hline Processing & 500.00 & 5.90 \\
\hline Total cost & 865.38 & 10.26 \\
\hline Net margin of miller & 500.00 & 5.90 \\
\hline $\begin{array}{l}\text { Value of husk @ Rs.5/kg assuming grain, } \\
\text { husk ratio of 90:10 per qtls. }\end{array}$ & 50 & 0.59 \\
\hline Total margin of miller & 550.00 & 6.49 \\
\hline $\begin{array}{c}\text { Sale price of miller/Purchase price of } \\
\text { retailer }\end{array}$ & 7549.34 & 89.56 \\
\hline \multicolumn{3}{|c|}{ Cost incurred by retailer } \\
\hline $\begin{array}{l}\text { Transportation charges from mandi to } \\
\text { shop }\end{array}$ & 50.00 & 0.59 \\
\hline Labour charges for loading and unloading & 30.00 & 0.35 \\
\hline Storage facilities & 50.00 & 0.59 \\
\hline Total cost & 130.00 & 1.54 \\
\hline Net margin of retailer & 750.00 & 8.89 \\
\hline $\begin{array}{c}\text { Sale price of retailer /Purchase price of } \\
\text { consumer }\end{array}$ & 8429.34 & $100 \%$ \\
\hline
\end{tabular}


Table.5 Price spread of black gram in Channel-I (P-CA-W-M-R-C)

\begin{tabular}{|c|c|c|c|}
\hline S. No. & Particular & Rs./qt. & \% share in consumer rupee \\
\hline $\mathbf{1 .}$ & Producers net price & $\mathbf{5 4 0 0 . 0 0}$ & $\mathbf{6 4 . 1 7 \%}$ \\
\hline $\mathbf{2 .}$ & & Cost incurred by & \\
\hline & Producer & 90.00 & $\mathbf{1 . 0 9 \%}$ \\
\hline & Commission agent & 92.32 & $\mathbf{1 . 1 1 \%}$ \\
\hline & Wholesaler & 303.30 & $\mathbf{3 . 6 6 \%}$ \\
\hline & Miller & 620.00 & $\mathbf{7 . 4 8 \%}$ \\
\hline & Retailer & 130.00 & $\mathbf{1 . 5 7 \%}$ \\
\hline & Total cost & 1235.62 & $\mathbf{1 4 . 9 1 \%}$ \\
\hline $\mathbf{3 .}$ & Margin of & \\
\hline & Commission agent & 250.00 & $\mathbf{3 . 0 2 \%}$ \\
\hline & Wholesaler & 350.00 & $\mathbf{4 . 2 2 \%}$ \\
\hline & Miller & 500.00 & $\mathbf{6 . 0 3 \%}$ \\
\hline & Retailer & 550.00 & $\mathbf{6 . 6 4 \%}$ \\
\hline & Total margin & $\mathbf{1 6 5 0 . 0 0}$ & $\mathbf{1 9 . 9 1 \%}$ \\
\hline $\mathbf{4 .}$ & Sale price of retailer/ purchase & $\mathbf{8 3 3 5 . 6 2}$ & $\mathbf{1 0 0 \%}$ \\
\hline & price of consumer & & \\
\hline
\end{tabular}

Table.6 Price spread of black gram in Channel-II (P-CA-M- R-C)

\begin{tabular}{|c|c|c|c|}
\hline S. No. & Particular & Rs./qt. & $\%$ share in consumer rupee \\
\hline 1. & Producers net price & 5550.00 & $66.48 \%$ \\
\hline 2. & \multicolumn{3}{|c|}{ Cost incurred by } \\
\hline & Producer & 90.00 & $1.05 \%$ \\
\hline & Commission agent & 94.60 & $1.19 \%$ \\
\hline & Miller & 865.34 & $17.96 \%$ \\
\hline & Retailer & 130.00 & $\mathbf{0 . 9 8 \%}$ \\
\hline & Total cost & 1174.26 & $19.20 \%$ \\
\hline \multirow[t]{5}{*}{3.} & \multicolumn{3}{|c|}{ Margin of } \\
\hline & Commission agent & 400.00 & $2.81 \%$ \\
\hline & Miller & 500.00 & $4.51 \%$ \\
\hline & Retailer & 750.00 & $8.45 \%$ \\
\hline & Total margin & 1650.00 & $15.78 \%$ \\
\hline 4. & $\begin{array}{l}\text { Sale price of retailer/purchase price of } \\
\text { consumer }\end{array}$ & 8429.34 & $100 \%$ \\
\hline
\end{tabular}

\section{Price spread of black gram in channel II}

The perusal of Table. 5 reveals that producer share in consumer rupee was 66.48per cent and price spread was high, out of which, 19.20 per cent was accounted for by marketing cost and 15.78 per cent was accounted for by margin.

Jhansi being one of the most prominent district of uttar Pradesh in pulse production and soil as well climatic conditions assist at 
the optimal in its production. As far marketing channels are considered, the cost of pulses are hiking to optimal due to large gap between demand and supply, there had been lateral crop failure and draught which resulted in the aforesaid situation. Primarily, there had been only two channel predominantly prevailing in the area and Moth and Jhansi mandi are the major market where study was undertaken.

Marketable and marketed surplus showed a tendency to increase with increase in farm size. There was no difference in marketable and marketed surplus as farmers were hard pressed by their cash needs. Black gram, channel II (Producer $\rightarrow$ Commission agent $\rightarrow$ Dal miller $\rightarrow$ Retailer $\rightarrow$ Consumer) was more efficient due to higher percent share of farmer in the consumer rupee and low price spread.

The analysis of marketing channels revealed that in channels I, marketing cost incurred by producer, commission agent, wholesaler, dal miller and retailer was 1.09, 1.17, 3.66, 7.48 and 1.57 per cent of consumer rupee, respectively. In channel II, marketing cost incurred by producer, commission agent, dal miller and retailer was $1.05,1.19,7.96$ and 0.98 per cent of consumer rupee, respectively. The analysis of relative share of producer per quintal of black gram revealed that channel II was more remunerative than channel I.

The economies of scale are not in favour of large farms mainly due to high cost per unit of output. Therefore the large farms should use their resources (capital and labour) optimally so that the scale economies tilt in their favour. Erratic electricity supply should be corrected so that farmers can adequately irrigate black gram crop. The problem of shortage of labour can be countered by popularizing manually operating black gram transplanted. The farmers can avoid distress sales by availing warehouse receipt loans. Quality control of insecticide/pesticide should be ensured in the market so that farmers get quality products. The malpractices in the market should also be checked so that farmers get fair deal.

\section{References}

Acharya S. P. Basavaraja H. Kunnal L. B. Mahajanashetti S. B. and Bhat A. R. S. (2012), "Growth in area, production and productivity of major crops in Karnataka" Karnataka Journal of Agricultural Sciences; 25(4):431-436. 10 ref.

Deoghare P. R. Chandra R. and Singh V. P. (1991), "An analysis of production, consumption and constraint to growth of pulses in India" Agricultural Situation in India; 46(5):291-294. 5 ref

Gupta S. K. (2001), "Economics of pulses production and identification of constraints in raising their production (a consolidated report of AERC studies)" Ad-hoc Study - AgroEconomic Research Center for Madhya Pradesh, Jawaharlal Nehru Krishi Vishwa Vidyalaya; 79, 177 pp.

Shamim M. and Saxena K. K., (2005), "A study on the marketable surplus and disposal of wheat, black gram and gram in Kanpur and Lucknow mundal of Uttar Pradesh" Farm Science Journal; 14(2):18-19.

\section{How to cite this article:}

Ameesh John Stephen, Rakesh Kumar Mishra and Setu Ratnam. 2021. Disposable Pattern of Black Gram in Jhansi District of Uttar Pradesh, India. Int.J.Curr.Microbiol.App.Sci. 10(12): 2835. doi: https://doi.org/10.20546/ijcmas.2021.1012.005 